\title{
Insulin Receptors on Monocytes of Young Healthy Persons Correlated with Glucose Tolerance and Insulin Sensitivity
}

\author{
H. Beck-Nielsen and O. Pedersen \\ Medical Department III and Department of Clinical Chemistry, County Hospital of Aarhus, Aarhus, Denmark
}

Summary. We have studied in normal man the interrelationships between insulin binding to monocytes, glucose tolerance and insulin sensitivity. In 25 young healthy persons we found a significant positive correlation between insulin binding and glucose disappearance rate both after glucose $(\mathrm{R}=0.68$, $\mathrm{p}<0.01)$ and insulin $(\mathrm{R}=0.49, \mathrm{p}<0.02)$ given intravenously.

Key words: Insulin receptors, monocytes, glucose tolerance, insulin sensitivity.

Several studies of the relation between insulin binding and the biological effects of insulin have been performed in vitro. Kono et al. [1] found in rat adipocytes an inhibitory effect of trypsin on both the specific insulin binding and the biological effect of insulin. Another strong argument for the relationship was advanced by Gliemann et al. [2, 3] and Freychet et al. [4, 5]. With a number of insulin analogues with altered binding affinity to isolated rat adipocytes and hepatocytes they found corresponding changes in the biological potency on these cells. Furthermore, Olefsky [6] has found that a decreased insulin binding in old, fat rats was coupled to a rightward shift in the insulin dose response curve for 2-deoxy-glucose uptake.

The purpose of the present study was to examine relations between the biological effect of insulin and insulin binding to monocytes in normal persons. The biological effect of insulin was estimated by the results of intravenous glucose tolerance tests and intravenous insulin sensitivity tests.

Insulin binding to monocytes is specific and insulin degradation is insignificant at $15^{\circ} \mathrm{C}$ [7]. It is sup- posed that the monocyte receptors for insulin have the same characteristics as insulin receptors in muscle cells, adipocytes and hepatocytes [8].

\section{Materials and methods}

\section{Subjects}

The study comprised 25 apparently healthy 21-33 years old volunteers $(84-113 \%$ of ideal body weight, Life Insurance Company, Geigy tables, 6th edition) randomly selected from the hospital staff. All ate a normal diet. Clinical data of the group are given in Table 1.

\section{Plasma Insulin and Glucose}

Plasma immunoreactive insulin was measured in duplicate by an alcohol precipitation method [9]. Plasma glucose was determined in duplicate using an o-toluidine method [10].

\section{Cell Binding Studies}

One hundred and seventyfive $\mathrm{ml}$ whole blood was drawn from an antecubital vein at $8 \mathrm{a} . \mathrm{m}$. after an overnight fast and transferred to tubes containing EDTA (dipotassium salt). Mononuclear leucocytes were isolated by gradient centrifugation [11]. The cells were washed twice and incubated in Tris- $\mathrm{HCl}$ buffer $\left(25 \mathrm{mmol} / \mathrm{l}, \mathrm{pH} 8.0\right.$ at $\left.15^{\circ} \mathrm{C}\right)$ at a concentration of about $70 \times 10^{6} / \mathrm{ml}$ [12] for $100 \mathrm{~min}$ at $15^{\circ} \mathrm{C}$ with $125 \mathrm{I}$-insulin (Novo Research Institute, Copenhagen) at a concentration of $172 \mathrm{pmol} / \mathrm{l}$. The specific activity of the tracer was about 25-30 $\mu \mathrm{Ci} / \mu \mathrm{g}$, with $0.1-0.2$ iodine atoms per insulin 
Table 1. Clinical and metabolic characteristics of the group studied

\begin{tabular}{|c|c|c|c|c|c|c|c|c|}
\hline $\mathrm{n}$ & M F & $\begin{array}{l}\text { Age } \\
\text { years }\end{array}$ & $\begin{array}{l}\text { Body weight } \\
\% \text { of ideal }\end{array}$ & $\begin{array}{l}\text { Fasting plasma } \\
\text { glucose conc. } \\
\mathrm{mmol} / \mathrm{l}\end{array}$ & $\begin{array}{l}\text { Fasting plasma } \\
\text { insulin conc. } \\
\mu \mathrm{U} / \mathrm{ml}\end{array}$ & $\begin{array}{l}\text { Specific } \\
\text { cell binding } \\
\text { fraction } \\
\times 10^{-2}\end{array}$ & $\begin{array}{l}\text { IVGTT } \\
\text { k-values } \\
10^{-2} \min ^{-1}\end{array}$ & $\begin{array}{l}\text { IVITT } \\
\mathrm{k} \text {-values } \\
10^{-2} \min ^{-1}\end{array}$ \\
\hline 25 & 1015 & $\begin{array}{l}25 \\
(21-33)\end{array}$ & $\begin{array}{l}101 \\
(84-113)\end{array}$ & $\begin{array}{l}5.0 \\
(4.5-5.9)\end{array}$ & $\begin{array}{l}5.1 \\
(0-15.1)\end{array}$ & $\begin{array}{l}2.3 \\
(1.3-4.4)\end{array}$ & $\begin{array}{l}1.8 \\
(1.0-3.0)\end{array}$ & $\begin{array}{l}5.8 \\
(3.1-7.0)\end{array}$ \\
\hline
\end{tabular}

molecule [13]. At this low degree of iodination more than $95 \%$ of the iodoinsulin is monoiodinated [14].

For competition studies native insulin in increasing concentrations was added to the incubation medium (see Fig. 5). At the end of the incubation period cell bound and free insulin was separated by centrifugation through silicone oil (density 1.04). "Specific cell binding" is defined as total binding fraction minus non-specific binding fraction. Radioactivity which remained bound in the presence of an excess of native insulin at $7000 \mathrm{nmol} / 1$ was considered "non-specific". This fraction averaged $25 \%$ of total binding. The monocytes were identified in cytocentrifuged smears stained with alpha naphthyl acetate esterase [15]. Monocytes comprised $14.5 \%$ of the mononuclear leucocytes. Median monocyte concentration was $9.6 \times 10^{6} / \mathrm{ml}$ (range $6.2-15.4 \times 10^{6} / \mathrm{ml}$ ). The specific cell binding fraction was adjusted to a cell number concentration of $10^{7}$ monocytes per $\mathrm{ml} \mathrm{[7].} \mathrm{All} \mathrm{binding} \mathrm{studies}$ were done in duplicate.

\section{Intravenous Glucose Tolerance Test (IVGTT) and Intravenous Insulin Sensitivity Test (IVITT)}

These tests were performed at the same occasions as the insulin receptor studies, i. e. in the morning after an overnight fast. A 30 min resting period was allowed between the blood sampling for receptor analysis and the intravenous injections. IVGTT was performed by injecting $25 \mathrm{~g}$ glucose during $4 \mathrm{~min}$. Blood samples were taken for glucose and insulin determination at time $-30,-15,0,2,5,10,15$, $20,30,45$ and $60 \mathrm{~min}$. The half-time of the plasma glucose decay was estimated from the log-linear phase of the plasma glucose concentrations plotted as a function of time. The rate constant $\mathrm{k}_{\mathrm{IVGTT}}$ was calculated from the formula: $0.693 / \mathrm{T}_{1 / 2}$ according to Lundbæk [16]. The median plasma glucose levels before and $60 \mathrm{~min}$ after the IV glucose load were not significantly different, whereas the plasma insulin concentration increased twofold: However, the rise in plasma insulin level caused by the glucose injection was negligible compared to the rise caused by exogenous insulin. After $60 \mathrm{~min} 0.1 \mathrm{U}$ crystalline insulin per kg body weight was injected intravenously. Blood samples for plasma glucose analyses were taken $5,10,15,20,25,30,35,40$ and 45 min after insulin injection. From 5 to $30 \mathrm{~min}$ after IV insulin the plasma glucose concentration declined linearly, and the $\mathrm{k}_{\text {IVITT }}$ was estimated over this time. The insulin sensitivity was expressed as the rate constant for plasma glucose disappearance, $\mathrm{k}_{\mathrm{IVITT}}$, estimated as $\mathrm{k}_{\text {IVGTT }}$. The combined glucose tolerance test and insulin sensitivity test used has been discussed by Alford et al. [17] who found no significant difference between $\mathrm{k}_{\mathrm{IVITT}}$-values obtained after fasting and after a glucose load.

\section{Insulin Secretion}

The plasma insulin concentration after the glucose load was plotted as a function of time; the area below the resulting curve calculated by planimetry expressed in arbitrary units was taken as an estimate of insulin secretion. The area under the insulin secretion curve from 0 to $10 \mathrm{~min}$ was considered an estimate of the initial insulin response.

\section{Statistical Methods}

Wilcoxon's two-sample test was employed for comparison of values between groups. In correlation studies Spearman's Rho test was used.

\section{Results}

Values of fasting plasma glucose concentration, fasting plasma insulin concentration, $\mathrm{k}_{\mathrm{IVGTT}}$ and $\mathrm{k}_{\mathrm{IVTTT}}$ and specific cell binding fraction are given in Table 1 . Two persons had a $\mathrm{k}_{\mathrm{IVGTT}}=1.0$, and are borderline cases for normal glucose tolerance. They were not excluded because our aim was to study relationships between the insulin binding and the glucose metabolism in a randomly selected group of young people with normal body weight.

The specific insulin binding at the tracer con- 


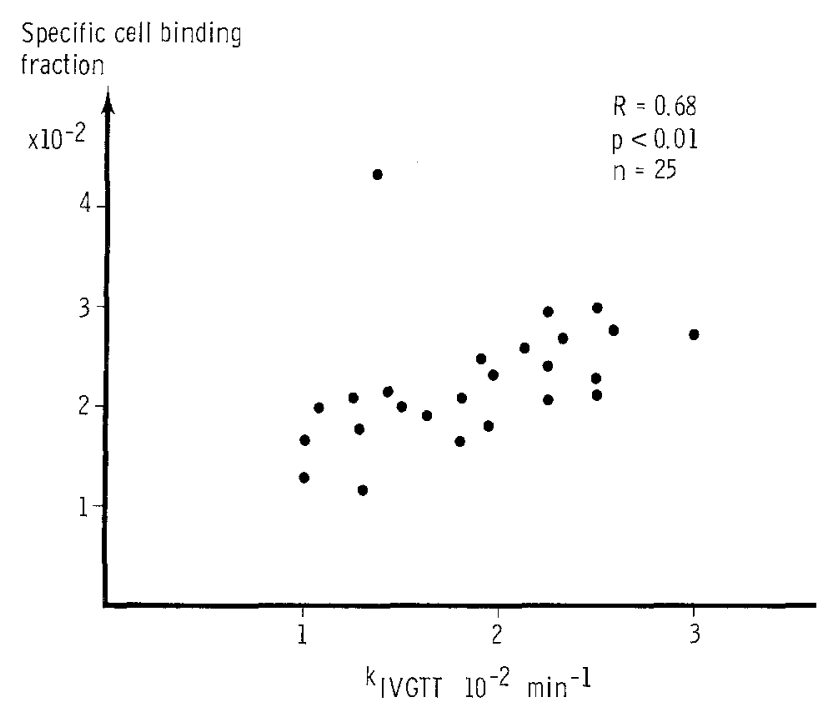

Fig. 1. Correlation between the specific cell binding fraction at the tracer concentration $(172 \mathrm{pmol} / 1)$ and the rate constant $\left(\mathrm{k}_{\text {rvGTT }}\right)$ for the glucose disappearance after a load of $25 \mathrm{~g}$ glucose IV

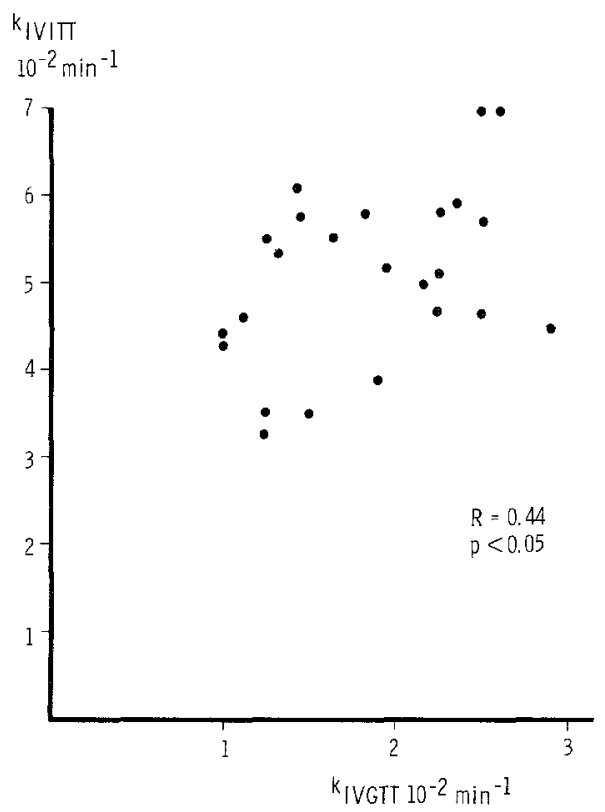

Fig. 3. Correlation between the rate constants for the glucose disappearance after injection of $25 \mathrm{~g}$ glucose IV $\left(\mathrm{k}_{\mathrm{IVGTT}}\right)$ and after injection of $0.1 \mathrm{U}$ insulin IV per $\mathrm{kg}$ body weight $\left(\mathrm{k}_{\text {IVTTT }}\right)$

centration $(172 \mathrm{pmol} / \mathrm{l}$, which is within the physiological range), was positively correlated with glucose tolerance $(\mathrm{R}=0.68, \mathrm{p}<0.01)$ and insulin sensitivity $(\mathrm{R}=0.49, \mathrm{p}<0.02)$ (Figs. 1,2$)$. No significant relationship could be demonstrated between the fasting plasma insulin concentration and the insulin binding at tracer concentration $(\mathrm{R}=0.18, \mathrm{p}>0.1)$. Furthermore there was no significant correlation be-
Specific cell binding

fraction

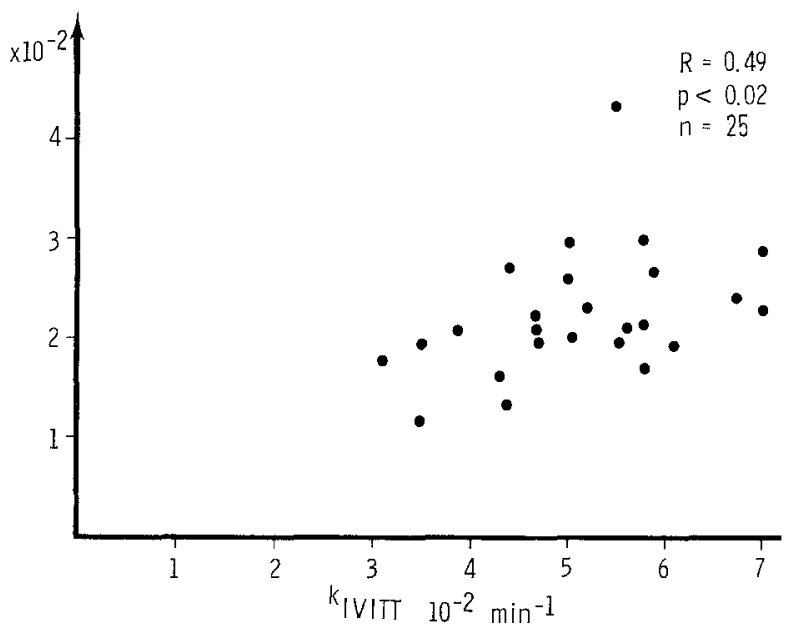

Fig. 2. Correlation between the specific cell binding fraction at the tracer concentration and the rate constant $\left(\mathrm{k}_{\text {IVITT }}\right)$ for the glucose disappearance after IV injection of $0.1 \mathrm{U}$ insulin $/ \mathrm{kg}$ body weight

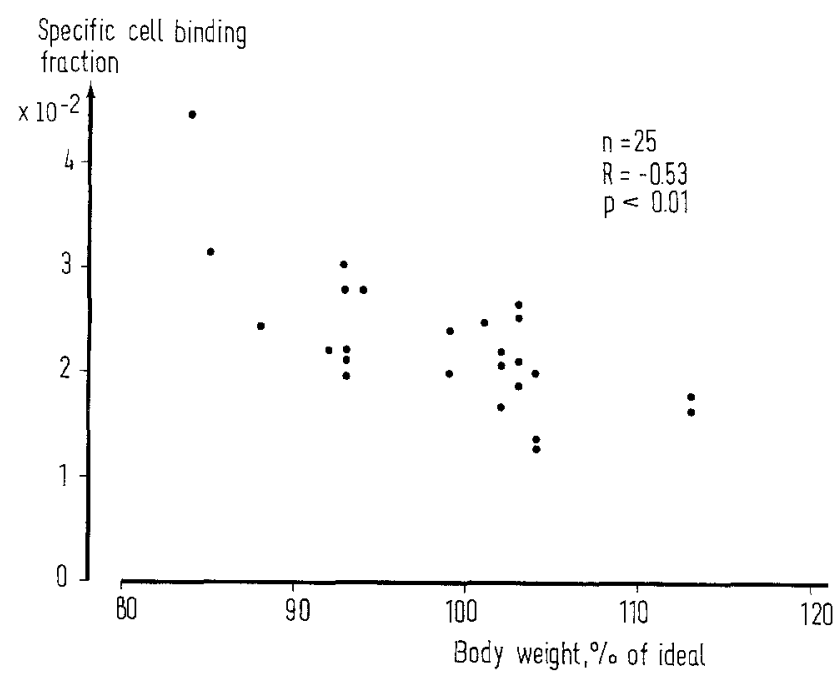

Fig. 4. The specific cell binding fraction at the tracer concentration as a function of the body weight expressed as percentage of ideal weight

tween insulin secretion from 0 to $60 \mathrm{~min}$ after glucose IV and insulin binding $(R=-0.20, p>0.1)$.

Figure 3 shows a positive correlation between $\mathrm{k}_{\text {IVGTT }}$ and $\mathrm{k}_{\text {IVITT }}(\mathrm{R}=0.44, \mathrm{p}<0.05)$. The glucose tolerance was correlated with the initial insulin response after glucose IV $(R=0.45, p<0.05)$ but unrelated to be total insulin response $(\mathrm{R}=-0.02$ $\mathrm{p}>0.1$ ). 


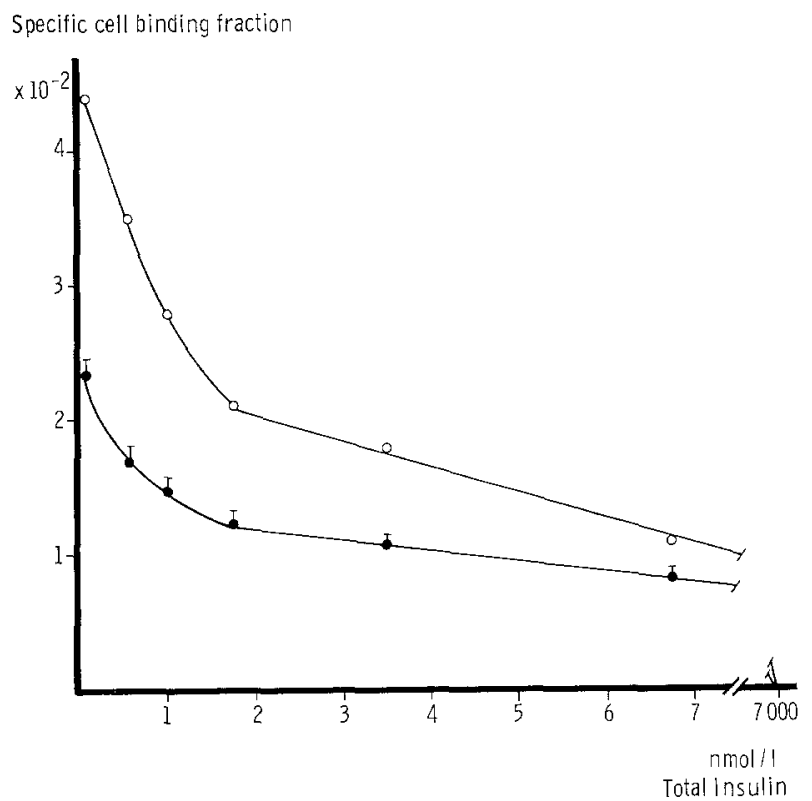

Fig. 5. The inhibiting effect of native insulin on the ${ }^{125} \mathrm{I}$-insulin binding to monocytes from a 22 year old relatively insulin deficient male ( 0 ) and the total group of volunters $(\bullet)$. Mononuclear leucocytes in a concentration of $70 \times 10^{6}$ per $\mathrm{ml}$ were incubated in a tris-HCL buffer $(\mathrm{pH}=8)$ at $15^{\circ} \mathrm{C}$ for 100 min with ${ }^{125} \mathrm{I}$-insulin in a concentration of $172 \mathrm{pmol} / \mathrm{l}$ and native insulin in increasing concentration. The specific cell binding fraction is corrected to a monocyte concentration of $10^{7} / \mathrm{ml}$. Each point on the curve for the group represents mean \pm SEM (1)

Body weight, expressed in percent of ideal weight, was negatively correlated with the specific cell binding fraction at the insulin tracer concentration $(\mathrm{R}=-0.53, \mathrm{p}<0.01)$ (Fig. 4).

\section{Discussion}

\section{Insulin Binding and Glucose Metabolism}

Luft and Cerasi [18] found that the insulin response to intravenous glucose challenge could be low in persons with normal glucose tolerance, and suggested that the glucose tolerance depends on both the insulin release and the insulin sensitivity.

In our present study there was a positive correlation between glucose tolerance and insulin sensitivity and between glucose tolerance and the initial insulin response after glucose IV. Moreover, we found insulin binding to be positively correlated with the glucose disappearance rate both after injection of glucose and insulin. Our data therefore suggest a close relation between the insulin receptor and the glucose disappearance rate in normal man. This is consistent with the reported animal experiments on insulin receptors and biological effects of insulin [1,
$2,3,4,5,6]$. Furthermore our results are in accordance with the recent report by Harrison et al. [19] who, in obese subjects, found a correlation between insulin binding to adipocytes and insulin sensitivity.

The present results add support to the concept that the monocyte receptor mirrors the insulin receptors of target tissues.

\section{Insulin Binding and Plasma Insulin Concentration}

Gavin et al. [20] found that in vitro high media insulin concentration led to decreased insulin receptor number on cultured human lymphocytes. An inverse correlation between insulin receptor concentration and fasting plasma insulin level has been repeatedly reported in chronic hyperinsulinaemic states $[21,22$, 23]. Our results from young normals fail to demonstrate such a relationship between the hormone and its receptor, which in part may be due to the small range in plasma insulin concentration among persons with normal body weight. However, the daytime plasma insulin concentration is usually elevated considerably above the fasting level. Therefore we have searched for a correlation between insulin secretion and insulin binding, but could not find any association.

One of our subjects had a specific cell binding fraction of $4.4 \times 10^{-2}$, which is about twice as high as the median value of the group (Fig. 5). This person was insulin deficient. His fasting insulin was low $(2 \mu \mathrm{U} / \mathrm{ml})$ and did not increase significantly after glucose intravenously or after meals. In the fasting state he had slightly elevated concentrations of plasma free fatty acids and ketones. The insulin receptors of this person apparently compensate for a poor beta cell function of the pancreas, because he still had a normal glucose tolerance $\left(\mathrm{k}_{\mathrm{IVGTT}}=1.4\right)$.

Acknowledgement. We are indebted to Dr. J. Gliemann and Dr. S. Gammeltoft, Institute of Physiology, University of Copenhagen, Ing. acad. H. Dalsager, Cand. pharm. P. Hardt, County Hospital of Aarhus, for constructive criticism and valuable advice; T. Skrumsager and L. Busch for skilful technical assistance; and $\mathrm{L}$. Thomsen for her careful preparation of the manuscript. The study was supported by grants from Danish Medical Research Council, Nordisk Insulin Fond, Landsforeningen for Sukkersyges Fond and Professor Aage Th. B. Jakobsens Fond.

\section{References}

1. Kono, T., Barham, F. W.: The relationship between the insulin binding capacity of fat cells and the cellular response to insulin. J. Biol. Chem. 246, 6210-6216 (1971)

2. Gliemann, J., Gammeltoft, S.: The biological activity and the binding affinity of modified insulins determined on isolated rat fat cells. Diabetologia 10, 105-113 (1974)

3. Gammeltoft, S., Gliemann, J.: The binding of insulins from 
different animal species to rat fat cell receptors. Acta Physiol. Scand. 91, 7 A-8 A (1974) (abstract)

4. Freychet, P., Roth, J., Neville, D.M., Jr.: Insulin receptors in the liver: Specific binding of $\left({ }^{125} \mathrm{I}\right)$ insulin to the plasma membrane and its relation to bioactivity. Proc. Natl. Acad. Sci. USA 68, 1833-1837 (1971)

5. Freychet, P., Brandenburg, D., Wollmer, A.: Receptor binding assay of chemically modified insulins. Comparison with in vitro and in vivo bioassays. Diabetologia 10, 1-5 (1974)

6. Olefsky, J.M.: The effects of spontaneous obesity on insulin binding, glucose transport and glucose oxidation of isolated rat adipocytes. J. Clin. Invest. 57, 842-851 (1976)

7. Beck-Nielsen, H., Pedersen, O., Kragballe, K., Sørensen, N.S.: The monocyte as a model for the study of insulin receptors in man. Diabetologia 13, 563-569 (1977)

8. Gavin, J.R. III, Gordon, P., Roth, J., Archer, J.A., Buell, D. N.: Characteristics of the human lymphocyte insulin receptor. J. Biol. Chem. 248, 2202-2207 (1973)

9. Heding, L.G.: A simplified insulin radioimmunoassay method. In: L. Donato et al. (Ed.): Labelled proteins in tracer studies, 345-350. Brussels: Eurotom 1966

10. Feteris, W. A.: A serum glucose method without protein precipitation. Am. J. Med. Technol. 31, 17-21 (1965)

11. Boyum, A.: Separation of leucocytes from blood and bone marrow. Scand. J. Clin. Labor. Invest. 21, 77-89 (1968)

12. Pedersen, O., Beck-Nielsen, H.: A study of insulin receptors in human mononuclear leucocytes. Acta Endocrinol. (Kbh.) 83, 556-564 (1976)

13. Jørgensen, K.H., Binder, C.: ${ }^{125}$ I-insulin as a tracer of insulin in different chemical processes. In: $\mathbf{L}$. Donato et al. (Ed.): Labelled proteins in tracer studies, 329-333. Brussels: Eurotom 1966

14. Freychet, P., Roth, J., Neville, D. M.Jr.: Monoiodoinsulin: demonstration of its biological activity and binding to fat cells and liver membranes. Biochem. Biophys. Res. Commun. 43, 400-408 (1971)

15. Yam, L. T., Li, C. Y., Crosby, W. N.: Cytochemical identification of monocytes and granulocytes. Am. J. Clin. Pathol. 55, 283-290 (1971)
16. Lundbæk, K.: Intravenous glucose tolerance as a tool in definition and diagnosis of diabetes mellitus. Br. Med. J. 1962 I, $1507-1513$

17. Alford, F.P., Martin, F. I. R., Pearson, M. J.: The significance and interpretation of mildly abnormal oral glucose tolerance. Diabetologia 7, 173-180 (1971)

18. Cerasi, E., Luft, R.: What is inherited - what is added. Hypothesis for the pathogenesis of diabetes mellitus. Diabetes 16, 615-627 (1967)

19. Harrison, L. C., Martin, F. I. R., Melick, R. A.: Insulin receptor binding in isolated fat cells and insulin sensitivity in obesity. J. Clin. Invest. 58, 1435-1441 (1976)

20. Gavin, J.R., III, Roth, J., Neville, D.M. Jr.: Insulin-dependent regulation of insulin receptor concentration: a direct demonstration in cell culture. Proc. Natl. Acad. Sci. USA 71, 84-88 (1974)

21. Olefsky, J.M.: Decreased insulin binding to adipocytes and circulating monocytes from obese subjects. J. Clin. Invest. 57, 1165-1172 (1976)

22. Beck-Nielsen, H., Pedersen, O., Bagger, J.P., Sørensen, N.S.: The insulin receptor in normal and obese persons. Acta Endocrinol. (Kbh.) 83, 565-575 (1976)

23. Bar, R. S., Gordon, P., Roth, J., Kahn, C. R.: Fluctuations in the affinity and concentration of insulin receptors on circulating monocytes of obese patients. J. Clin. Invest. 58, 1123-1135 (1976)

Received: April 22, 1977,

and in revised form: October 12, 1977

Henning Beck-Nielsen

Medical Department III

County Hospital

Tage Hansensgade

DK-8000 Aarhus C

Denmark 